\title{
FEATURE
}

\section{Conservation tillage is not conservation agriculture}

\author{
Don C. Reicosky
}

\section{A LOOMING COLLISION: GLOBAL POPULATION AND FOOD SECURITY}

As world population increases and food production demands rise, keeping our soil healthy and productive while protecting the environment is of paramount importance for agriculture. The expanding global population-expected to reach 9.5 billion people by 2050 (United Nations 2014) - is putting tremendous pressure on the finite land area and resources for agricultural production, and pending climate extremes exacerbate the challenge of food security for both developed and developing countries.

Despite the lessons of history, soil erosion is still a major problem in agricultural production systems. Efforts to control land degradation and soil erosion can be traced over the last 10,000 years; humankind has been building on the ruins of the past tillage and monoculture concepts at our peril (Lal et al. 2007; Montgomery 2007a, 2007b). Montgomery (2007b) describes the effects of poor soil management and erosion on several past civilizations. Once thriving, these civilizations eventually collapsed due to erosion, salinization, nutrient depletion, and other types of soil degradation. Tillage for soil preparation for planting and cultivation, by loosening soil and easing its transport by wind or water, induces and increases erosion. We are losing soil faster than nature can make it. In fact, Montgomery (2007b) calculated average soil formation of 0.017 to $0.036 \mathrm{~mm}$ ( 0.00067 to 0.00142 in) a year-equivalent to 700 to 1,500 years to form an inch $(25 \mathrm{~mm})$ of soil. In Collapse: How Societies Choose to Fail or Succeed, Diamond states that at least 10 of the 12 most important environmental problems we face "are also central to agronomy, crop science and soil science. Agricultural sustainability, in other

Don C. Reicosky is a research soil scientist emeritus, retired from the USDA Agricultural Research Service, Morris, Minnesota. words, is the heart of global sustainability" (Diamond 2005).

Approaches to soil conservation are in constant evolution and improvement (Dumanski and Peiretti 2013).There is also a continuum of conservation approaches for preparation of soil for planting. At one extreme, conventional tillage usually involves aggressive mechanical inversion of soil that leads to unintended consequences of high rates of soil organic carbon (C) loss, disruption of the soil biology, and erosion by wind and rain. No-tillage (zero tillage) leaves most soil undisturbed, providing protection from erosion and loss of $\mathrm{C}$ to the atmosphere. Conservation tillage (CT), or "any tillage sequence, the object of which is to minimize or reduce loss of soil and water; operationally, a tillage or tillage and planting combination which leaves a $30 \%$ or greater cover of crop residue on the surface" (Soil Science Glossary Terms Committee 2008), is ambiguously intermediate and covers a broad range of soil disturbance and crop residue incorporation between these two extremes (Derpsch et al. 2014). The objectives of this review are to discuss the definition and merits of CT and to illustrate the complexities and the benefits of conservation agriculture (CA) as a sustainable form of agricultural production that can also contribute to global food security.

\section{SOILS: A LIVING SYSTEM}

Soils are alive, are extremely complex, and play essential roles in our food and water security, ecosystem services, climate change adaptation and mitigation, poverty alleviation, and sustainable development, as well as global environmental change and human evolution on earth.They provide anchorage for plant roots, serve as support for plants to capture C in photosynthesis, hold water long enough for plants to make use of it, and hold and recycle nutrients that sustain life. Soils also serve as a home to numerous microorganisms (bacteria, fungi, protozoa, nematodes, algae, earthworms, soil insects, burrowing animals, etc.) that accomplish many biochemical transformations-from fixing atmospheric nitrogen $(\mathrm{N})$ to the decomposition of organic matter.

Because the soil is alive, it must be treated appropriately. For example, mycorrhiza fungi produce glomalin (glue-like substance) that improves the soil structure and pore space over time. Better soil structure allows more rainfall to soak into the soil profile. Fungi are rather delicate and populations are reduced with tillage; however, if the soil is not disturbed, the numbers will increase over time. The term "soil health" is preferred by some (Doran et al. 1996; Doran and Safley 1997) because it portrays soil whose functions are mediated by a diversity of living organisms that require management and conservation. For farmers, soil health is a key component of good production. The simple slogan "healthy soil, healthy plants and animals, healthy people" is often used to describe the CA system. Understanding that the soil is a living biological system brings the practice of tillage, bent on fracturing and stirring the soil, under scrutiny. This is especially critical because stirring of the top 5 to $8 \mathrm{~cm}$ (2 to 3 in) of soil results in increased runoff.

DEFINITION OF CONSERVATION TILLAGE Conservation tillage includes a broad set of practices with a goal leaving some crop residue on the soil's surface to increase water infiltration and reduce erosion. The various practices described as "conservation tillage" have led to terminology confusion. Conservation tillage is often confused with no-till or variants of CT described in vague terms, such as such as minimum tillage, mulch tillage, ridge tillage, strip tillage, and reduced tillage, where planting is achieved on specially prepared surfaces with various amounts of crop residue cover (Hobbs 2007; Dumanski and Peiretti 2013; Derpsch et al. 2014). These definitions of CT and the use of jargon send a mixed and confusing mes- 
sage (CTIC 1999). Mannering and Fenster (1983) define CT as a broad term used with "any" tillage system with the primary objective of "reducing soil and water loss" and agree that this has caused confusion. The term most confusing is "minimum tillage," defined as "the minimum use of primary and/or secondary tillage necessary for meeting crop production requirements under the existing soil and climatic conditions, usually resulting in fewer tillage operations than for conventional tillage" (Soil Science Glossary Terms Committee 2008; Mannering and Fenster 1983). To some it could mean merely reducing the number of tillage trips from eight to six. Both farmers and researchers are confused by the terminology and its inconsistent use.

Baker et al. (2002) identified 14 names for reduced tillage: zero-tillage, chemicalplowing, stale-seedbed, chemical fallow, no-till, direct-seeding, disc drilling, drillage, sod-seeding, minimum-tillage/ reduced-tillage, strip-tillage/zone-tillage, ridge-tillage/ridge-till, and residue farming. They defined CT as "the collective umbrella term commonly given to notillage, direct-drilling, minimum-tillage, and/or ridge-tillage, to denote that the specific practice has a 'conservation goal' of some nature. Usually, the retention of $30 \%$ surface cover by residues characterizes the lower limit of classification for CT, but other conservation objectives may include conservation of time, fuel, earthworms, soil, water, soil structure, and nutrients. Thus, residue levels alone do not adequately describe all CT practices" (Baker et al. 2002).

Conservation tillage suggests reduced tillage intensity compared to moldboard plow inversion that includes a wide range of soil disturbance and residue incorporation. Examples of CT in the field are illustrated in figure 1. No-till or direct seeding has

\section{Figure 1}

Collection of several different types of "conservation tillage" tools and planters illustrating a wide range of tillage depths and degrees of residue incorporation (from left to right and top to bottom): (a) conventional inversion moldboard plow, (b) paraplow, (c) deep ripper combination tool, (d) deep field cultivator combination tool, (e) field cultivator tool rigid tine (photo courtesy of the Natural Resources Conservation Service [NRCS]), (f) deep field cultivator spring tine (photo courtesy of NRCS), (g) deep field cultivator rigid tine, (h) heavy-duty disk harrow (photo courtesy of NRCS), (i) normal duty disk harrow, (j) shallow field cultivator spring tine, (k) vertical tillage tool (photo courtesy of NRCS), (l) high disturbance strip tillage implement combination tool, (m) strip/zone tillage implement in wheat stubble, (n) strip tillage implement combination tool rigid tine, (o) disc opener no-till planter into alfalfa stubble, and ( $p$ ) disc opener no-till planter into dead residue (photo courtesy of Dave Brandt).

(a)

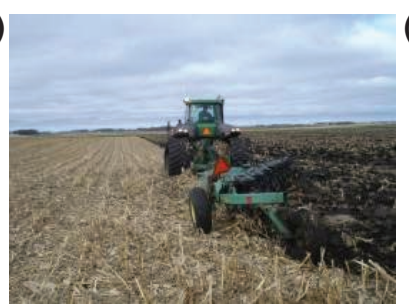

(e)

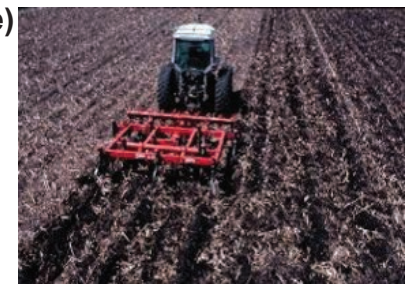

(i)

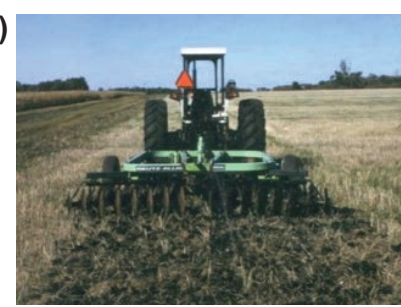

(m)

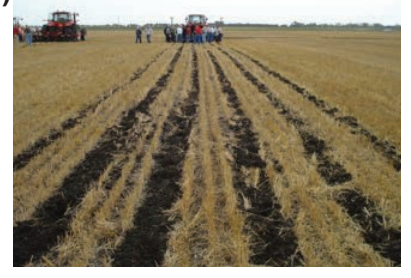

(b)

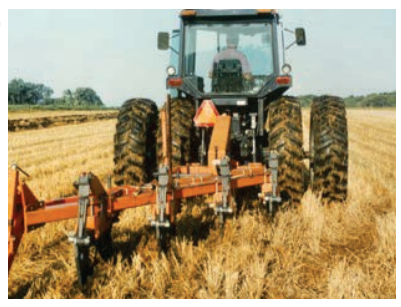

(f)

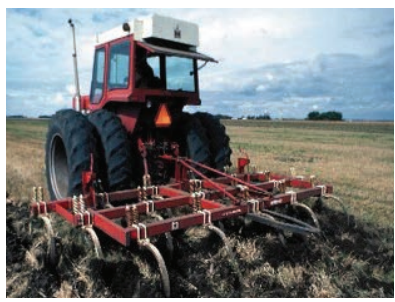

(j)

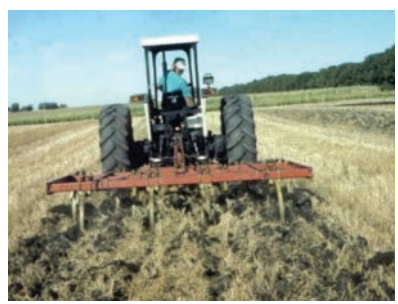

(n)

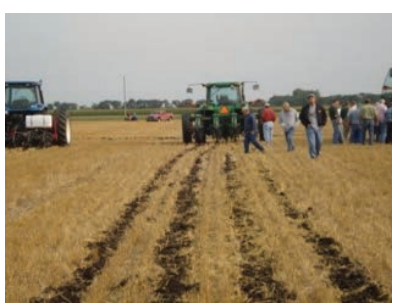

(c)

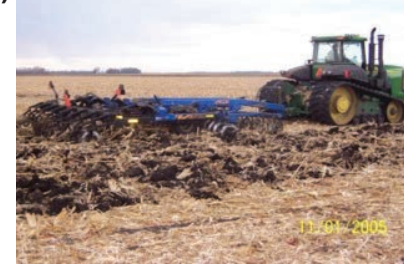

(g)

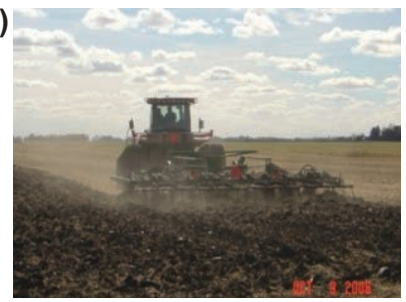

(k)

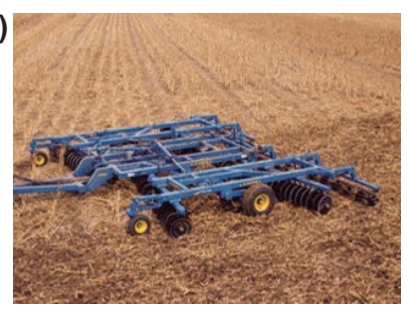

(o)

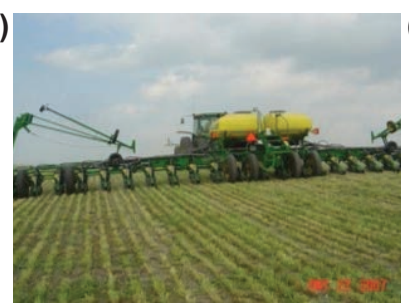

(d)

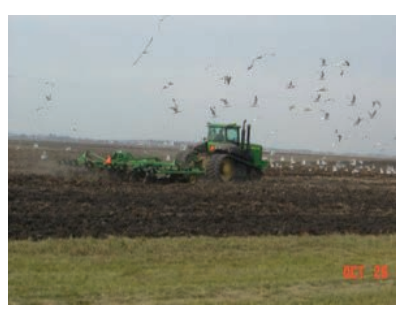

(h)

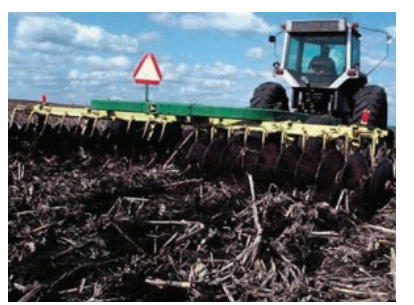

(I)

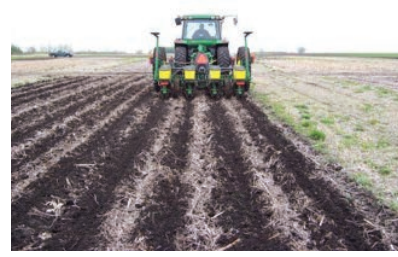

(p)

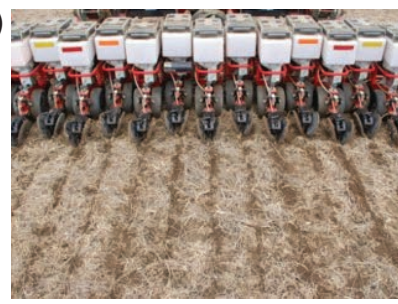


often been included in the broad class of CT, but perhaps should be considered as a separate class for CA with minimum soil disturbance quantified. When we consider the soil as a living system, minimum soil disturbance and residue incorporation must be considered to meet the objectives of improved soil health and soil protection. Strip tillage equipment leaves disturbed strips of various widths and depths with the inter-row undisturbed. Chisel plows can have rigid or spring tines and typically operate 100 to $150 \mathrm{~mm}$ (4 to 6 in) deep, mixing the soil and leaving some crop residue on the surface. Using combination tools for deep ripping utilizes subsoil shanks that penetrate to about $380 \mathrm{~mm}$ (15 in) deep and heavy disks to cut the residue and redistribute/level the soil surface. The wide range of soil disturbance and residue incorporation has consequences in fuel consumption since less fuel is consumed with less soil disturbed. Less residue incorporation provides more soil protection during erosion events. Often, characteristics of soil disturbance and residue incorporation are not quantified, adding to the confusion and uncertainty about the extent of soil conservation and research with CT techniques.

The lack of quantitative information on the volume of soil disturbed and the degree of residue incorporation or residue left on the soil surface in CT has been detrimental to the research community (Derpsch et al. 2014). The basic goal of $30 \%$ residue cover for soil and water conservation is generally met; however, the soil conditions may be quite varied. The confusion with the definition of CT is illustrated in the conceptual diagram in figure 2 . The chart shows the relative volume of soil disturbed versus the different types of tillage/seeding methods. The left side of the chart represents the moldboard plow with a large volume of soil disturbed (conventional tillage) that progressively decreases through several types of CT implements to minimum soil disturbance with low disturbance no-till/ direct seed planters (no-tillage) on the extreme right. Everything in between the extremes is considered CT and is not listed in quantitative order, reflecting ambiguous definitions. Quantitative data on both

\section{Figure 2}

Schematic representation of the volume of soil disturbed with a wide range of conservation tillage (CT)/seeding implements from inversion tillage with the moldboard plow on the left to the low disturbance no-till planter on the right. All forms of CT are between these extremes and are listed in a suggested qualitative order. HD = high disturbance and LD $=$ low disturbance. Source: modified after Friedrich Tebrügge.
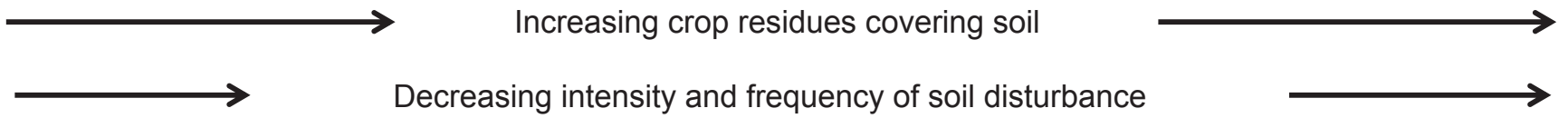

$\begin{array}{ccc}\begin{array}{c}\text { Conventional } \\ \text { tillage }\end{array} & \text { Conservation } & \text { No } \\ \text { tillage } & \text { tillage }\end{array}$

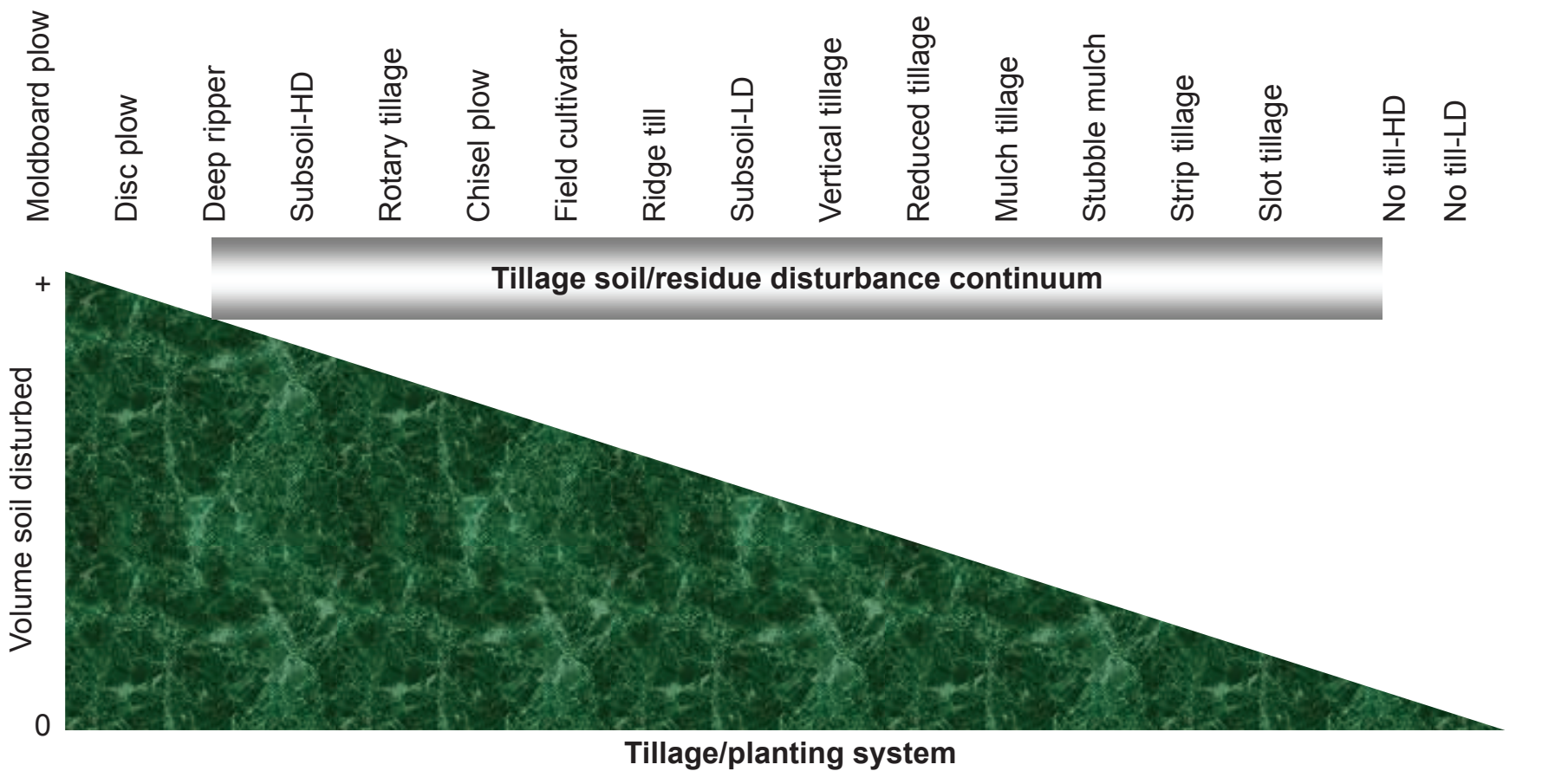


volume of soil disturbed and degree of residue incorporation or residue left on the soil's surface are needed for better understanding the conservation benefits of the resulting disturbed surface because of their impact on the rate of evaporation, residue decomposition, and nutrient cycling in crop production.

Tillage is not something nature does and should not be considered a conservation objective (Faulkner 1944). This statement raises the question, "How has the conservation community accepted and used CT over the last five decades?" Conservation tillage terminology was first used when chisel plows were widely used in the late 1960s. This tool left more residue on the soil's surface with soil disturbance extent a function of the operating depth. However, in many cases multiple tillage trips resulted in full width disturbance and little residue left on the soil's surface. Regardless, use of the term "conservation tillage" remained. The phrase "conservation tillage" has become, at times, an oxymoron; it sends a mixed and confusing message and gives a misguided sense of entitlement and conservation because of very "loose limits" on the definition of soil disturbance and residue management. Conservation is a word to be respected, revered, and used to describe agriculture, not tillage.

Soil erosion continues to be a major problem in production agriculture (Montgomery 2007b). Even with several types of CT, soil is being lost faster than nature can make it. Seta et al. (1993) measured soil erosion after moldboard plow inversion tillage, CT (practiced in this study as chisel-plow tillage with straightshanks), and no-till (direct seeding); results are shown in table 1. Conventional plow tillage and disc harrowing had the largest sediment loss, CT had intermediate loss, and no-till had the least sediment loss. Sediment lost from conventional plow tillage was 52 times greater than the no-till treatment, while CT was 11 times greater than the no-till treatment.

A second example of soil erosion with conservation tillage systems is illustrated by Dickey et al. (1984). They stated, "the term 'conservation tillage, as used in this paper, includes all tillage methods that leave at least $20 \%$ of the soil surface covered with residues after planting." A summary of their two-year data enabled comparison of three different conservation tillage systems with various depths 10 to $25 \mathrm{~cm}$ (4 to $10 \mathrm{in}$ ) deep and degrees of residue incorporation that fall between the conventional tillage system (moldboard plow plus disk harrow) and no-till. As expected, the residue cover was largest on the no-till treatment and decreased to the minimum on the moldboard plow treatment. Correspondingly, soil loss was largest from the moldboard plow treatment and lowest from the no-till treatment, showing the importance of residue cover. The measured soil erosion showed a decrease that appeared to be partly related to tillage intensity and partly due to residue cover. Even though these treatments were loosely called conservation tillage, there was much more erosion relative to the notill treatment, in general agreement with the work of Seta et al. (1993).

\section{Table 1}

Soil loss from conventional, conservation, and no-till systems showing total runoff, sediment concentration, sediment loss, and relative sediment loss compared to the no-till system. Means or totals in a column followed by a different lowercase letter are significantly different $(p<0.05)$. Adapted with permission from table 1 of Seta et al. (1993).

\begin{tabular}{|c|c|c|c|c|}
\hline Tillage type & $\begin{array}{l}\text { Total runoff } \\
(\mathrm{mm})\end{array}$ & $\begin{array}{l}\text { Sediment concen- } \\
\text { tration }\left(\mathrm{g} \mathrm{L}^{-1}\right)\end{array}$ & $\begin{array}{l}\text { Sediment loss } \\
\left(\mathrm{Mg} \mathrm{ha}^{-1}\right)\end{array}$ & $\begin{array}{l}\text { Sediment } \\
\text { relative loss }\end{array}$ \\
\hline $\begin{array}{l}\text { Conventional (moldboard } \\
\text { plowing to a depth of } 18 \mathrm{~cm} \\
\text { followed by two diskings) }\end{array}$ & $45.0 b$ & $36.4 c$ & $15.5 c$ & 52 \\
\hline $\begin{array}{l}\text { Conservation (chisel-plow } \\
\text { tillage with straight-shank } \\
\text { chisel plow) }\end{array}$ & $28.9 b$ & $12.5 b$ & $3.3 b$ & 11 \\
\hline No tillage (direct seeding) & 7.6a & $4.7 a$ & $0.3 a$ & 1 \\
\hline
\end{tabular}

The significant soil loss from the CT treatments suggests that, despite the accepted $30 \%$ residue cover, many types of CT do not adequately protect the soil from raindrop impact and are not sustainable. Other CT tools would give varying amounts of soil erosion, based on soil volume disturbance and residue cover. North Dakota State University Extension soil specialist Dave Franzen said, "Conservation tillage is better, but it is not good enough." (Personal communication, January 7, 2015). Most "conservation tillage" is more "tillage" than "conservation." It makes technical sense, environmental sense, financial sense, and common sense to stop soil erosion to maintain food security. While the goals of $\mathrm{CT}$ are laudable, present-day CT methods are not adequately protecting our soils.

\section{DEFINITION OF CONSERVATION AGRICULTURE}

The first use of the phrase "conservation agriculture" (CA) came out of a LatinAmerican Network for Conservation Tillage meeting sponsored by the Food and Agriculture Organization of the United Nations (FAO) in Morelia, Michoacán, Mexico, in 1997 (Rolf Derpsch, personal communication, April 9, 2015). Conservation agriculture was introduced by the FAO (2008) as a concept for resource-efficient agricultural crop production based on integrated management of soil, water, and biological resources combined with external inputs. It has been promoted by institutions and organizations with the expectation that it can contribute to sustainable intensification (Hobbs 2007; Hobbs et al. 2008; FAO 2011) and has spread into other regions of the world to become a global agricultural movement (Friedrich et al. 2012; Kassam et al. 2014b). Recent reviews of CA have been published by Hobbs (2007), Hobbs et al. (2008), Dumanski et al. (2006), Baker et al. (2006), Goddard et al. (2008), Govaerts et al. (2009); Kassam et al. (2009), Friedrich et al. (2012), Kassam et al. (2014a), and Farooq and Siddique (2015).

The definition of CA incorporates system concepts based on three key principles: (1) continuous residue cover on the soil surface; (2) continuous minimum soil dis- 
turbance (no-tillage); and (3) diverse crop rotations and cover crop mixes (Hobbs 2007; Hobbs et al. 2008; Kassam et al. 2009; FAO 2011; Friedrich et al. 2012; Derpsch et al. 2014). Soil cover can be either live cover crops, terminated cover crops, or mulches of crop residues remaining after previous harvests that accumulate on the soil surface. Retaining mulch between crops provides better protection against erosion and can also maintain higher soil moisture in dry regions; enrich the soil with organic matter; and, if the mulch is sufficiently dense, prevent the regrowth of weeds. Diversified cropping patterns composed of at least three species including at least one legume are suggested. To incorporate more diversity, some farmers are using 10 to 12 species in cover crop mixes (usually after small grain). While these three main principles are general in their application, specific differences in each principle need to be defined clearly to avoid confusion. The no-till system employed in CA is not to be confused with other forms of CT that substantially disturb the soil surface. The success of the CA system concepts rely on and benefit from the interactive synergies between the biological, physical, and chemical properties and processes in the soil that enhance C management. Farmers using CA principles and concepts globally are cultivating more than $1.55 \times 10^{8}$ ha $\left(3.83 \times 10^{8} \mathrm{ac}\right.$; Kassam et al. 2014b).

True conservation is more about plant C (residue) management than soil management. The interest in cover crops and $\mathrm{C}$ input stems from the potential for "drought proofing" a landscape. Soil organic matter increases water-holding capacity, absorbs moisture (Hudson 1994), then slowly releases water promoting nutrient cycling. By using cover crops and diverse crop rotations in CA, some farmers report than they believe their soil may have more available water for their crops when those crops really need it. While there is data showing that cover crops will compete for water (Unger and Vigil 1998; Daigh et al. 2014; Nielson et al. 2015), any increase in water use efficiency with cover crop mixes in CA may be due to improved infiltration, increased storage capacity (macropores and micropores), and decreased soil evapo- ration with crop residue mulch on the soil surface. The synergistic simplicity of notill (minimizes $\mathrm{C}$ and soil loss) and the use of diverse rotations and cover crop mixes (maximizes soil coverage and $\mathrm{C}$ input) for soil diversity protection and regeneration benefits CA.

Conservation agriculture and soil health system concepts are closely related to $\mathrm{C}$ management, and the implementation of CA with mostly undisturbed soils, diverse rotations, and cover crop mixes is the most "natural" form of production agriculture. The system exploits the diversity and synergy of living organisms that shape each particular ecosystem with soil $\mathrm{C}$ as the primary energy source. When soil is not tilled, beneficial changes include an increase in soil life, increases in soil C content and a change in the way nutrients cycle in the soil. Churning the soil can release significant amounts of carbon dioxide $\left(\mathrm{CO}_{2}\right)$ into the atmosphere (Reicosky and Lindstrom 1993; Ellert and Janzen 1999; Reicosky and Archer 2007). Without tillage, there are more environmental benefits accrued with fewer input costs over time. Many farmers are finding the hand-in-hand environmental and economic benefits of this systems approach for food security.

Conservation agriculture is also climatesmart agriculture, making the transition to farming better suited to the impacts of climate extremes that jeopardize food security (Rosenzwieg et al. 2002). We can no longer afford to separate the future of food security from that of our natural resources (Palm et al. 2014); the environment and climate change are inextricably intertwined, and our management response must be as well (Lal et al. 2012).

\section{SUMMARY}

Soils are the fundamental foundation of our food security. The various approaches to soil conservation, including no-tillage, CT, and CA, are components of a continuum of conservation approaches applicable at different levels. No-tillage, as a primary principle of $\mathrm{CA}$, provides direct benefits to agriculture and environmental issues both at the local and international levels. The conversion and incremental transition to improve soil conservation has been an educational evolution that the scientific community must understand and continue for future generations. Conservation tillage, although well intentioned, does not always provide enough soil erosion protection and water conservation. Present day implementation of CA principles and concepts will be a way to cope with food production during climate extremes. Both the public and policy groups must understand the importance of CA for food security for modern civilizations. Local farmer knowledge, innovative farmers, research support, farmer-run associations, and policy support are all necessary elements to iteratively improve designs and equipment for particular regions and soil types in global adoption of CA. The many farmers using CA principles and concepts globally can't all be wrong (Kassam et al. 2014b).

\section{ACKNOWLEDGEMENTS}

The author would like to acknowledge helpful suggestions and discussions with Rolf Derpsch, Dan Towery, Clark Gantzer, and several other scientists and conservation agriculture farmers.

\section{REFERENCES}

Baker C.J, K.E. Saxton, and W.R. Ritchie. 2002. No-Tillage Seeding: Science and Practice. 2nd ed. Oxford, UK: CAB International.

Baker, C.J., K.E. Saxton, W.R. Ritchie, W.C.T. Chamen, D.C. Reicosky, M.F.S. Ribeiro, S.E. Justice, and P.R. Hobbs. 2006. No-Tillage Seeding in Conservation Agriculture, 2nd ed. Oxford, UK: CAB International/Food and Agriculture Organization of the United Nations. CTIC (Conservation Technology Information Center). 1999. What's Conservation Tillage? Lafayette, IN: CTIC, Core 4 Program.

Daigh, A.L., M.J. Helmers, E. Kladivko, X. Zhou, R. Goeken, J. Cavdini, D. Barker, and J. Sawyer. 2014. Soil water during the drought of 2012 as affected by rye cover crops in fields in Iowa and Indiana. Journal of Soil and Water Conservation 69(6):564-573, doi:10.2489/jswc.69.6.564.

Derpsch, R., A.J. Franzluebbers, S.W. Duiker, D.C. Reicosky, K. Koeller, W.G. Sturny, J.C.M. Sá, and K. Weiss. 2014. Why do we need to standardize no-tillage research? Soil \& Tillage Research 137:16-22. 
Diamond, J. 2005. Collapse: How Societies Choose to Fail or Succeed, Revised Edition. New York: Penguin Books.

Dickey, Elbert C., D.P. Shelton, P.J.Jasa, and T. Peterson. 1984. Tillage, residue and erosion on moderately sloping soils. Transactions of the American Society of Agricultural Engineers 27(4):1093-1099.

Doran, J.W., M. Sarrantonio, and M. Liebig. 1996. Soil health and sustainability. In Advances in Agronomy, Vol. 56, ed. D.L. Sparks. San Diego, CA:Academic Press.

Doran, J.W., and M. Safley. 1997. Defining and assessing soil health and sustainable productivity. In Biological Indicators of Soil Health, eds. C, Pankhurst, B.M. Doube, and V.V.S.R. Gupta, V.V.S.R. Wallingford, Oxon, UK: CAB International.

Dumanski, J., and R. Peiretti. 2013. Modern concepts of soil conservation. International Soil and Water Conservation Research 1(1):19-23.

Dumanski, J., R. Peiretti, J.R. Benites, D. McGarry, and C. Pieri. 2006. The paradigm of conservation tillage. Proceedings of World Association of Soil and Water Tillage, Paper P1-7, 58-64.

Ellert, B.H., and H.H. Janzen. 1999. Short-term influence of tillage on $\mathrm{CO}_{2}$ fluxes from a semiarid soil on the Canadian Prairies. Soil Tillage Research 50:21-32.

FAO (Food and Agriculture Organization). 2008. Conservation Agriculture. http://www.fao.org/ $\mathrm{ag} / \mathrm{ca} /$ index.html.

FAO. 2011. Save and Grow: A Policymaker's Guide to the Sustainable Intensification of Smallholder Crop Production 1-37.

Farooq,M., and K.H.M.Siddique. 2015. Conservation agriculture:Concepts, brief history, and impacts on agricultural systems. In Conservation Agriculture, eds. M. Farooq and K.H.M. Siddique, 3-17. Springer International Publishing Switzerland, doi:10.1007/978-3-319-11620-4_1.

Faulkner, E.H. 1944. Plowman's Folly. Norman, OK: University of Oklahoma Press.

Friedrich, T., R. Derpsch, and A.H. Kassam. 2012. Overview of the global spread of Conservation Agriculture. Facts Reports, Special Issue 6:1-7.

Goddard, T., M. Zoebisch, Y. Gan, W. Ellis, A. Watson, and S. Sombatpanit. 2008. No-till Farming Systems. Special Publication [3]:544. Bangkok: World Association of Soil and Water Conservation (WASWC).

Govaerts, B., N. Verhulst, A. Castellanos-Navarrete, K.D. Sayre, J. Dixon, and L. Dendooven. 2009. Conservation agriculture and soil carbon sequestration: Between myth and farmer reality. Critical Reviews in Plant Sciences 28:97-122.
Hobbs, P.R. 2007. Conservation agriculture: What is it and why is it important for future sustainable food production? Journal of Agricultural Science 145:127-137.

Hobbs, P.R., K. Sayre, and R. Gupta. 2008. The role of conservation agriculture in sustainable agriculture. Philosophical Transactions of the Royal Society B 363(1491):543-555.

Hudson, B.D. 1994. Soil organic matter and available water capacity. Journal Soil and Water Conservation 49:189-194.

Kassam, A., R. Derpsch, and T. Friedrich. 2014a. Global achievements in soil and water conservation: The case of Conservation Agriculture. International Soil and Water Conservation Research 2(1):5-13.

Kassam, A., T. Friedrich, R. Derpsch, and J. Kienzle. 2014b. Worldwide Adoption of Conservation Agriculture. 6th World Congress of Conservation Agriculture, 22-27 June 2014, Winnipeg, Canada. http://www.ctic.org/WCCA/.

Kassam, A., T. Friedrich, F. Shaxson, and J. Pretty. 2009. The spread of conservation agriculture: Justification, sustainability, and uptake. International Journal of Agricultural Sustainability 7(4):292-320.

Lal, R., J.A. Delgado, J. Gulliford, D. Nielsen, C.W. Rice, and R.S.Van Pelt. 2012. Adapting agriculture to drought and extreme events. Journal of Soil and Water Conservation 67(6):162A-166A, doi:10.2489/jswc.67.6.162A.

Lal, R., D.C. Reicosky, and J.D. Hanson. 2007. Evolution of the plow over 10,000 years and the rationale for no-till farming. Soil Tillage Research 93:1-12.

Mannering, J.V., and C.R. Fenster. 1983. What is conservation tillage? Journal of Soil and Water Conservation 38(3):140-143.

Montgomery, D.R. 2007a. Dirt: The Erosion of Civilizations. Berkeley, CA: University of California Press.

Montgomery, D.R. 2007b. Soil erosion and agricultural sustainability. Proceedings of the National Academy of Sciences of the United States of America 104:13,268-13,272.

Nielsen, D.C., D.J. Lyon, G.W. Hergert, R.K. Higgins, FJ. Calderon, and M.F. Vigil. 2015. Cover crops in mixtures do not use water differently than single-species plantings. Agronomy Journal 107:1025-1038.

Palm, C., H. Blanco-Canqui, F. DeClerck, and L. Gatere. 2014. Conservation agriculture and ecosystem services: An overview. Agriculture Ecosystems and Environment 187:87-105.
Reicosky, D.C., and D.W. Archer. 2007. Moldboard plow tillage depth and short-term carbon dioxide release. Soil Tillage Research 94:109-121.

Reicosky, D.C., and M.J. Lindstrom. 1993. Fall tillage method: Effect on short-term carbon dioxide flux from soil. Agronomy Journal 85:1237-1243.

Rosenzweig, C., F.N. Tubiello, R. Goldberg, E. Mills, and J. Bloomfield. 2002. Increased crop damage in the US from excess precipitation under climate change. Global Environmental Change 12(3):197-202.

Seta, A.K., R.L. Blevins, W.W. Frye, and B.J. Barfield. 1993. Reducing soil erosion and agricultural chemical losses with conservation tillage. Journal Environmental Quality 22:661-665.

Soil Science Glossary Terms Committee. 2008. Glossary of soil science terms. Madison, WI: Soil Science Society of America.

Unger, P.W., and M.F.Vigil. 1998. Cover crop effects on soil water relationships. Journal of Soil and Water Conservation 53(3):200-207.

United Nations. 2014. Concise Report on the World Population Situation, 2014. Washington, DC: United Nations Department of Economic and Social Affairs. 